\title{
Preparation of protein powder from the liver of Yellowfin tuna (Thunnus albacores): a comparison of acid- and alkali-aided $\mathrm{pH}$-shifting
}

\author{
Kejing SHEN ${ }^{2 *}$, Wenting $\mathrm{MU}^{1 *}$, Shuqian XIA ${ }^{1 *}$, Yuting $\mathrm{CHEN}^{1}$, Huilin REN ${ }^{1}$, Xiangyun $\mathrm{XIE}^{1}$, Yizhou FANG ${ }^{1 *} \mathbb{0}$, \\ Guangrong HUANG ${ }^{1}$
}

\begin{abstract}
For the high-value utilization of tuna liver, the effects of acid-aided (Acid-pH) and alkali-aided pH-shifting (Alkali-pH) on the physicochemical and functional properties of the protein powder prepared by $\mathrm{pH}$-shifting and freeze-drying were studied. As expected, the protein powder with high purity could be obtained through Acid-pH or Alkali-pH followed by freeze drying, while the Alkali-pH led to a higher protein yield, higher protein ratio, lower lipid ratio and lower heavy metal content than Acid-pH. The amino acid profile of the protein powder prepared by Alkali-pH (Alkali-PP) was similar with that prepared by Acid-pH (Acid-PP). In addition, compared with Acid-PP, the Alkali-PP possessed the greater capacities in emulsion activity, foaming capacity and fat absorption capacity. Furthermore, the foaming capacity, foam stability and fat absorption capacity of Alkali-PP was better than soy protein powder. Therefore, Alkali-pH followed by freeze-drying would be a better alternative to prepare high-quality protein powder from tuna liver in the food industry.
\end{abstract}

Keywords: protein powder; pH-shifting; acid-aided and alkali-aided; heavy metal; functional properties.

Practical Application: Alkali-pH followed by freeze-drying is an available way to prepare high-quality protein powder from raw tuna liver.

\section{Introduction}

Yellowfin tuna (Thunnus albacores) is one of the largest commercially fished seafoods worldwide, with an annual output of 2-3 million tons. Liver from tuna is an abundant and underutilized by-product, which often ends up in animal feed or landfills (Daniel et al., 2016; Fang et al., 2019). However, tuna liver is characterized by a high protein level, and can be used as a potential source of protein powder. Protein powder, as a product of economic value, is widely used as additives, such as emulsifiers, adhesives, gelling agents and nutritional supplements, in processed foods for human consumption (Pires et al., 2012). In addition, other scholars (Pires et al., 2012) have reported that the protein obtained from marine species often exhibits better functional or bioactive properties than vegetable protein, which might be due to the special living environment in the ocean. Thus, production of protein powder from low-value tuna liver can contribute to the upgrading of this raw material.

pH-shifting, which mainly includes protein solubilization and isoelectric precipitation, combined with freeze-drying is a suitable alternative method by which to prepare protein powder from underutilized by-products. Furthermore, this method has been applied in the preparation of protein powder from marine species (Pires et al., 2012; Neves et al., 2017; Navarro-Peraza et al., 2020). During the protein solubilization process of $\mathrm{pH}$-shifting, the acid or alkali extraction can be alternatively selected because the protein is highly soluble in particular acidic or alkaline solutions; this is called acid- $\mathrm{pH}$-shifting (Acid-pH) or alkali-aided $\mathrm{pH}$-shifting (Alkali-pH), respectively. Nevertheless, the choice of Acid-pH or Alkali-pH not only impacts the recovery yield of protein but can also influence the composition and structure of the obtained protein (Antigo et al., 2018). Therefore, the use of Acid-pH or Alkali-pH depends on the characteristics of the matrix. However, the data available on the physicochemical properties of yellowfin tuna liver protein powder prepared by Acid-pH and Alkali-pH are limited. Hence, it is meaningful to compare the differences of protein powder quality prepared by both Acid-pH and Alkali-pH.

The objective of this study was to analyse the effects of Acid-pH and Alkali-pH on the physicochemical, nutritional and functional properties of obtained protein powder, in order to identify the better alternative and provide reliable guidance for the deep-processing of tuna liver in industry. 


\section{Materials and methods}

\subsection{Raw material}

The liver of yellowfin tuna (Thunnus albacores) was used as raw material in this study, which was purchased from China Fisheries Zhoushan Marine Fisheries Co., Ltd. (Zhejiang, China). The yellowfin tuna was captured in May 2019 from the Pacific Ocean, processed directly on board and stored in a frozen state $\left(-18{ }^{\circ} \mathrm{C}\right)$ until use. Before protein preparation, the liver was thawed overnight below $4{ }^{\circ} \mathrm{C}$.

\subsection{Protein solubility at different $p H$ values}

In order to optimize the parameters of Acid-pH and Alkali-pH, the effect of $\mathrm{pH}$ on protein solubility was investigated. The liver was homogenized with distilled water at a ratio of 1:9 $(\mathrm{g} / \mathrm{mL})$. Then, the $\mathrm{pH}$ of the mixture was adjusted to $1.5,2.0$, 2.5, 3.0, 3.5, 5.0, 5.5, 6.0, 6.5, 7.0, 10.0, 10.5, 11.0, 11.5 and 12.0, respectively. The $0.5 \mathrm{~mol} / \mathrm{L} \mathrm{HCl}$ or $\mathrm{NaOH}$ solution was used to adjust the $\mathrm{pH}$ of the mixture. After adjustment for $\mathrm{pH}$, the mixture was stirred for $5 \mathrm{~min}$ and then centrifuged at $8,000 \mathrm{~g}$ for $10 \mathrm{~min}$. The protein concentration in the supernatant was determined by the Kjeldahl method ( $\mathrm{Ba} 4 \mathrm{a}-38$ ) described in American Oil Chemists' Society (2009).

\subsection{Preparation of protein powder by pH-shifting}

The protein was recovered from the liver by $\mathrm{pH}$-shifting according to the methodology described by Pires et al. (2012). First, the protein in liver was dissolved in particular acidic or alkaline solutions, and the solids and lipids were removed by centrifugation; second, the dissolved protein was recovered by isoelectric precipitation, and separated with water by centrifugation; third, the residual water was removed by freeze-drying, and the residue after freeze-drying was high-purity protein powder. The $\mathrm{pH}$ values used in Acid-pH and Alkali-pH were decided depending on the results of protein solubility at different $\mathrm{pH}$ values (see section 2.2).

The prepared protein powder was vacuum-packed, and frozen at $-18{ }^{\circ} \mathrm{C}$ immediately after preparation. The protein powders prepared by Acid-pH and Alkali-pH were marked as Acid-PP and Alkali-PP, respectively.

\subsection{Proximate composition}

The proximate compositions, including moisture, protein, lipids and ash, of raw material, Acid-PP and Alkali-PP were determined following the methodology described in AOCS (American Oil Chemists' Society, 2009). The oven-drying method, Soxhlet method, Kjeldahl method and combustion method were selected for the determination of moisture, protein, lipids and ash, respectively.

\subsection{Amino acid analysis}

The amino acid analyser (L8900, Hitachi, Japan) and $\mathrm{Na}^{+}$ cation-exchange column $(4.6 \mathrm{~mm} \times 60 \mathrm{~mm}, 3 \mu \mathrm{m})$ were applied for the determination of amino acid content in raw material,
Acid-PP and Alkali-PP. The samples were hydrolyzed for $18 \mathrm{~h}$ in $6 \mathrm{~mol} / \mathrm{L} \mathrm{HCl}$ under $110^{\circ} \mathrm{C}$, then the hydrolysate was submitted to the amino acid analyser. In addition, $440 \mathrm{~nm}$ (for Pro) or $570 \mathrm{~nm}$ (for the others) was chosen to detect the separated amino acids.

\subsection{Heavy metal content}

The determination of heavy metal content was performed in ICP-MS. The mixture of $0.5 \mathrm{~g}$ protein sample, $5 \mathrm{~mL}$ Nitric acid and $2 \mathrm{~mL} \mathrm{H}_{2} \mathrm{O}_{2}(30 \%$, v/v) was digested with the heating procedure as follows: raised to $130{ }^{\circ} \mathrm{C}$ with a holding time of $5 \mathrm{~min}$, then further raised to $190^{\circ} \mathrm{C}$ at a rate of $6^{\circ} \mathrm{C} / \mathrm{min}$ with a final holding time of $20 \mathrm{~min}$. After digesting, the residue was blown down with $\mathrm{N}_{2}$ gas to approximate $1 \mathrm{ml}$, and then diluted to $50 \mathrm{~mL}$ by distilled water. Finally, the diluent was submitted to ICP-MS.

\subsection{Functional properties}

The functional properties, including emulsifying activity (EA), emulsifying stability (ES), foaming capacity (FC), foaming stability (FS), fat absorption capacity (FAC) and solubility, were measured based on the methods described by Fang et al. (2020) with little modification. In addition, the commercial soy protein powder (SPP), which was purchased from Macklin Co., Ltd. (Shanghai, China), was also studied and compared

EA and ES: the emulsion was prepared by mixing protein solution (1\%,w/w) and peanut oil (purchased from Gold Arowana Co., Ltd., Zhejiang, China) in a homogenizer operated for $30 \mathrm{~s}$ at $8,000 \mathrm{rpm}$. After homogenization, $50 \mu \mathrm{L}$ emulsion diluted to $5 \mathrm{~mL}$ sodium dodecyl sulfate solution $(0.1 \%$, w/w). The absorbance of the mixture was measured at $500 \mathrm{~nm}$ immediately after dilution and after $30 \mathrm{~min}$. The calculating formulas of EA were described in detail by Pires et al. (2012).

FC and FS: the $100 \mathrm{~mL}$ protein solution $(1 \%$, w/w) was homogenized for $1 \mathrm{~min}$ at $10,000 \mathrm{rpm}$. Then the mixture was immediately transferred to a $150 \mathrm{~mL}$ graduated cylinder, and the volumes of foam at first and after $30 \mathrm{~min}$ were measured.

FAC: a protein sample weighing $0.5 \mathrm{~g}$, was placed into $10 \mathrm{~mL}$ peanut oil. The mixture was stirred for $5 \mathrm{~min}$, and then centrifuged for $10 \mathrm{~min}$ at 4,000 g. The oil weight adsorbed by the protein was measured.

Solubility: the protein solubility in distilled water was measured using the same method described in section 2.2.

\subsection{Statistical analysis}

The IBM SPSS statistics software with a version of 20.0 (SPSS Inc., Chicago, IL) was used for statistical analysis. The one-way ANOVA followed by Tukey's test was applied to judge the significant differences $(p<0.05)$ between samples.

\section{Results and discussion}

\subsection{Optimization of Acid-pH and Alkali-pH}

The solubility of tuna liver protein with the change of $\mathrm{pH}$ values is a key to obtaining the maximum protein recovery of 
$\mathrm{pH}$-shifting. Figure 1 shows the solubility of tuna liver protein at different $\mathrm{pH}$ values, which was in accordance with a similar study in fish (Chen et al., 2016).

When the $\mathrm{pH}$ changed from 1 to 12 , the solubility of liver protein showed a trend of first decreasing and then increasing. At a $\mathrm{pH}$ of 5.5, the lowest solubility was observed, which indicated the isoelectric point of liver protein was close to 5.5 . When the $\mathrm{pH}$ increased or decreased, the solubility increased, and the highest solubility was found at a $\mathrm{pH}$ of 2.0 or 12.0. This was due to the protein turning to positive or negative when the $\mathrm{pH}$ was away from the isoelectric point, and further led to the enhancement of electrostatic repulsion and hydration (Chen et al., 2016). According to the above results, the optimal $\mathrm{pH}$ in the protein solubilization process of Acid-pH or Alkali-pH was 2.0 or 12.0, respectively, and the optimal $\mathrm{pH}$ in the isoelectric precipitation process was 5.5.

\subsection{The yield of protein recovery}

The protein recovery yield of Acid-pH and Alkali-pH under optimal conditions (see 3.1) is shown in Figure 2.

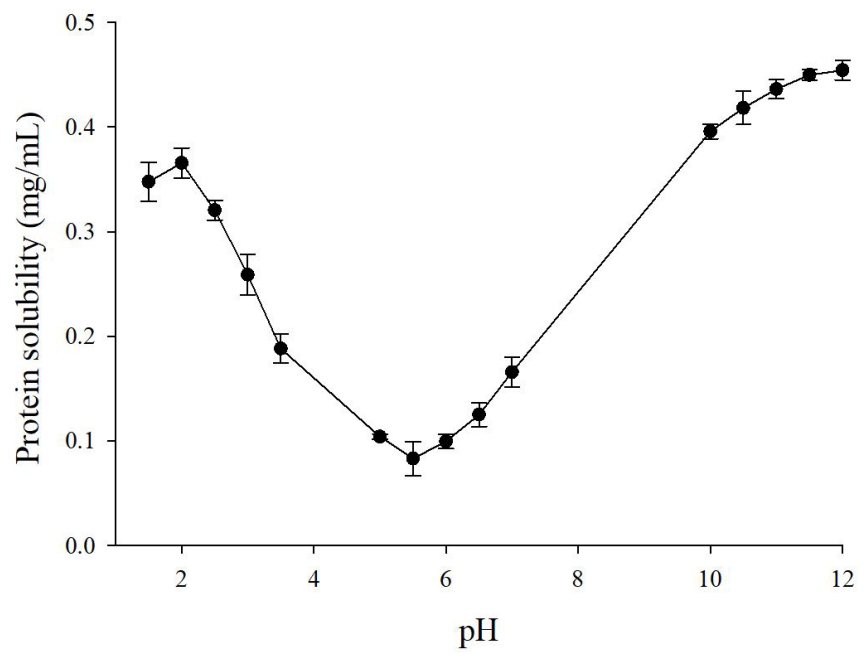

Figure 1. The solubility of tuna liver protein at different $\mathrm{pH}$ values.

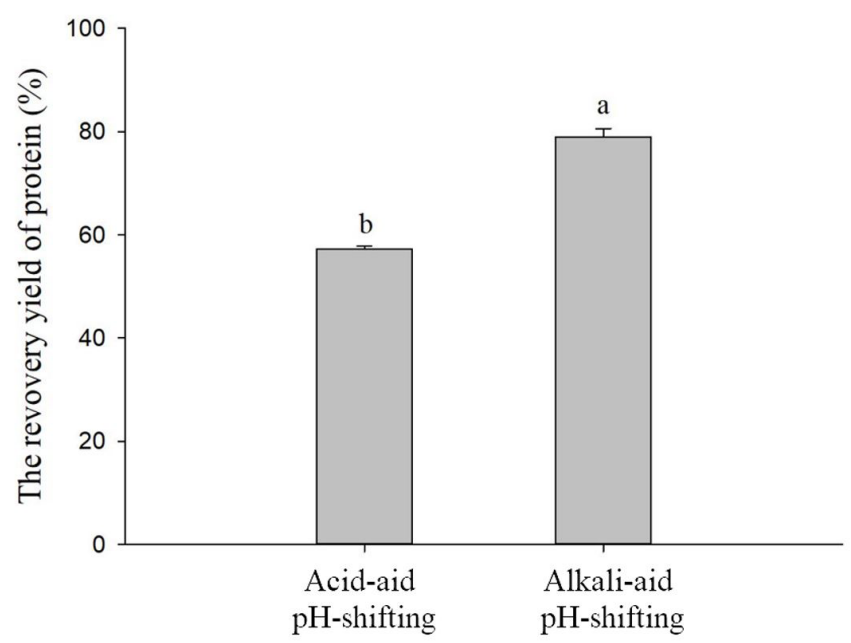

Figure 2. The protein recovery of Acid-aid and Alkali-aided pH-shifting.
The protein recovery of Acid-pH was $57.22 \%$, which was significantly lower $(p<0.05)$ than that of Alkali-pH (78.98\%). The lower solubility in the strong acid compared to the strong alkali (see Figure 1) might contribute to the lower protein recovery of Acid-pH. Moreover, part of the protein was denatured under a strong acid environment, which also led to the loss of protein. These results were in agreement with the relevant reports (Taskaya et al., 2010; Piotrowicz \& Salas-Mellado, 2017).

\subsection{Proximate composition}

The proximate composition of raw material and prepared protein powders areshown in Table 1.

As expected, the lipids and water in liver could be removed effectively by $\mathrm{pH}$-shifting and freeze-drying, respectively. Therefore, the protein powder with a high purity was finally obtained. However, the content of ash was increased significant $(p<0.05)$ after both Acid-pH and Alkali-pH, which may be due to the concentration effect.

Between Acid-PP and Alkali-PP, there was no significant difference $(p>0.05)$ in the contents of moisture and ash. However, the lipids content in Acid-PP (5.41\%) was significantly higher $(p<0.05)$ than in Alkali-PP $(2.71 \%)$. Under the alkaline condition, the saponification of lipids was predicted to occur, and the fatty acid salts were further formed (Kristinsson et al., 2010). However, the fatty acid salts could be more easily removed than lipids, which led to the lower lipids content of Alkali-PP. In addition, the protein content of Acid-PP (79.03\%) was significant lower $(p<0.05)$ than that of Alkali-PP $(81.56 \%)$, which might be due to the lower lipids removal capacity of Acid-pH than Alkali-pH.

\subsection{Amino acid profile}

The amino acid profile of different samples is listed in Table 2.

Most of the amino acids showed statistical differences $(p<0.05)$ between untreated tuna liver and the protein powder prepared by $\mathrm{pH}$-shifting, except Ala, Phe and His. During $\mathrm{pH}$-shifting, large amounts of water were applied in the process of protein solubilization and isoelectric precipitation, which would lead to the loss of amino acids and the change in the amino acid profile. In addition, the content of total essential amino acids (TEAAs) and the ratio of TEAAs to total amino acids (TAAs) in tuna liver were significantly reduced $(p<0.05)$ after being treated by $\mathrm{pH}$-shifting. This indicated that more

Table 1. The proximate composition of liver and the protein powders prepared by acid- (Acid-PP) and alkali-aided (Alkali-PP) pH-shifting.

\begin{tabular}{lcccc}
\hline & $\begin{array}{c}\text { Moisture } \\
(\%)\end{array}$ & Protein (\%) & Lipids (\%) & Ash (\%) \\
\hline Liver & $57.08 \pm 1.82^{\mathrm{a}}$ & $15.67 \pm 0.63^{\mathrm{a}}$ & $22.30 \pm 1.86^{\mathrm{a}}$ & $1.48 \pm 0.23^{\mathrm{a}}$ \\
Acid-PP & $10.07 \pm 0.59^{\mathrm{b}}$ & $79.03 \pm 1.03^{\mathrm{b}}$ & $5.41 \pm 0.25^{\mathrm{b}}$ & $2.45 \pm 0.12^{\mathrm{b}}$ \\
Alkali-PP & $9.88 \pm 0.19^{\mathrm{b}}$ & $81.56 \pm 0.21^{\mathrm{c}}$ & $2.71 \pm 0.79^{\mathrm{c}}$ & $2.31 \pm 0.22^{\mathrm{b}}$ \\
\hline
\end{tabular}

a,b,c, Different letters within a column demonstrated significant difference $(p<0.05)$. 
Table 2. Amino acid profile of liver and the protein powders prepared by acid- (Acid-PP) and alkali-aided (Alkali-PP) pH-shifting, with the unit of $\mathrm{mg} \mathrm{AA} / \mathrm{g}$ protein.

\begin{tabular}{|c|c|c|c|c|}
\hline & Liver & Acid-PP & Alkali-PP & $\begin{array}{l}\text { Requirements } \\
\text { for adults }\end{array}$ \\
\hline Asp & $66.00 \pm 4.79^{\mathrm{a}}$ & $85.71 \pm 1.94^{\mathrm{b}}$ & $85.65 \pm 1.42^{b}$ & \\
\hline Thr* & $61.77 \pm 6.30^{\mathrm{a}}$ & $43.30 \pm 1.03^{b}$ & $43.57 \pm 0.96^{\mathrm{b}}$ & 23 \\
\hline Ser & $53.59 \pm 5.23^{\mathrm{a}}$ & $80.37 \pm 1.88^{\mathrm{b}}$ & $80.93 \pm 1.08^{\mathrm{b}}$ & \\
\hline Glu & $132.06 \pm 7.02^{\mathrm{a}}$ & $194.99 \pm 2.99^{b}$ & $205.61 \pm 3.52^{c}$ & \\
\hline Pro & $53.60 \pm 6.09^{a}$ & $37.64 \pm 0.52^{\mathrm{b}}$ & $40.30 \pm 1.30^{c}$ & \\
\hline Gly & $43.40 \pm 4.82^{\mathrm{a}}$ & $36.03 \pm 0.78^{b}$ & $34.23 \pm 0.67^{c}$ & \\
\hline Ala & $38.85 \pm 4.57^{\mathrm{a}}$ & $41.61 \pm 0.45^{\mathrm{a}}$ & $41.12 \pm 1.98^{\mathrm{a}}$ & \\
\hline Cys & $42.55 \pm 3.51^{\mathrm{a}}$ & $15.78 \pm 0.33^{\mathrm{b}}$ & $17.72 \pm 0.60^{c}$ & \\
\hline $\mathrm{Val}^{*}$ & $78.48 \pm 4.47^{\mathrm{a}}$ & $51.14 \pm 1.65^{\mathrm{b}}$ & $56.88 \pm 1.69^{c}$ & 39 \\
\hline Met $^{*}$ & $55.69 \pm 3.84^{\mathrm{a}}$ & $30.96 \pm 1.42^{\mathrm{b}}$ & $31.88 \pm 0.70^{\mathrm{b}}$ & 16 \\
\hline $\mathrm{Ile}^{*}$ & $78.47 \pm 3.83^{\mathrm{a}}$ & $42.59 \pm 0.44^{\mathrm{b}}$ & $43.80 \pm 1.24^{\mathrm{b}}$ & 30 \\
\hline Leu $^{*}$ & $50.42 \pm 2.93^{\mathrm{a}}$ & $64.83 \pm 0.64^{\mathrm{b}}$ & $49.55 \pm 2.26^{\mathrm{a}}$ & 59 \\
\hline Tyr & $28.96 \pm 1.96^{\mathrm{a}}$ & $33.91 \pm 0.46^{\mathrm{b}}$ & $33.39 \pm 1.02^{\mathrm{b}}$ & \\
\hline $\mathrm{Phe}^{*}$ & $33.84 \pm 3.99^{\mathrm{a}}$ & $35.09 \pm 1.30^{\mathrm{a}}$ & $33.25 \pm 0.77^{a}$ & 30 \\
\hline Lys $^{*}$ & $25.49 \pm 1.05^{\mathrm{a}}$ & $46.49 \pm 1.00^{\mathrm{b}}$ & $48.14 \pm 0.95^{\mathrm{b}}$ & 45 \\
\hline $\mathrm{His}^{*}$ & $31.80 \pm 3.42^{\mathrm{a}}$ & $27.50 \pm 1.21^{\mathrm{a}}$ & $27.33 \pm 2.14^{a}$ & 15 \\
\hline Arg & $67.40 \pm 4.84^{\mathrm{a}}$ & $77.38 \pm 3.01^{\mathrm{b}}$ & $75.59 \pm 1.36^{\mathrm{b}}$ & \\
\hline TAA & $942.36 \pm 17.57^{\mathrm{a}}$ & $945.31 \pm 4.82^{\mathrm{a}}$ & $948.94 \pm 10.20^{\mathrm{a}}$ & \\
\hline TEAA & $415.96 \pm 15.63^{\mathrm{a}}$ & $341.89 \pm 1.86^{\mathrm{b}}$ & $334.40 \pm 8.23^{\mathrm{b}}$ & \\
\hline $\begin{array}{l}\text { TAA/ } \\
\text { TEAA } \\
(\%)\end{array}$ & $44.13 \pm 0.89^{\mathrm{a}}$ & $36.17 \pm 0.02^{\mathrm{b}}$ & $35.24 \pm 0.66^{\mathrm{b}}$ & \\
\hline
\end{tabular}

TAA: total amino acids; TEAA: total essential amino acids; ${ }^{\star}$ Essential amino acids for humans; ${ }^{a, b, c}$ Followed by different letters in the same line demonstrated significant difference $(p<0.05)$.

essential amino acids were lost compared with non-essential amino acids during $\mathrm{pH}$-shifting, which was in accord with the report by Teh et al. (2014).

Moreover, there was no significant difference $(p>0.05)$ in the majority of amino acids between Acid-PP and Alkali-PP, except in Glu, Pro, Gly, Cys, Val and Leu. Compared with Alkali-PP, the contents of Gly and Leu in Acid-PP were meaningfully higher $(p<0.05)$, and significantly lower $(p<0.05)$ in the contents of Glu, Pro, Cys and Val. This difference might be due to the differences in the solubility of amino acids under acidic or alkaline conditions. However, no significant difference $(p>0.05)$ was found in the content of TEAA and the ratio of TEAA to TAA between Acid-PP and Alkali-PP. Furthermore, almost all the contents of EAA in prepared Acid-PP and Alkali-PP could meet the requirements for adults established by World Health Organisation (Joint WHO/FAO/ UNU Expert Consultation, 2007), only the content of Leu in Alkali-PP was slightly lower than the requirement for adults. Therefore, the the prepared Acid-PP and Alkali-PP both had a high nutritional value for humans.
Table 3. The heavy metal content of liver and the protein powders prepared by acid- (Acid-PP) and alkali-aided (Alkali-PP) pH-shifting, with the unit of ppm.

\begin{tabular}{lccc}
\hline $\begin{array}{l}\text { Heavy } \\
\text { metal }\end{array}$ & Liver & Acid-PP & Alkali-PP \\
\hline $\mathrm{Cr}$ & $\mathrm{ND}$ & $1.05 \pm 0.04^{\mathrm{a}}$ & $0.55 \pm 0.06^{\mathrm{b}}$ \\
$\mathrm{Cu}$ & $18.45 \pm 0.30$ & $102.53 \pm 0.70^{\mathrm{a}}$ & $42.86 \pm 0.33^{\mathrm{b}}$ \\
$\mathrm{Zn}$ & $42.78 \pm 0.67$ & $278.32 \pm 1.90^{\mathrm{a}}$ & $152.86 \pm 0.68^{\mathrm{b}}$ \\
$\mathrm{As}$ & $3.39 \pm 0.25$ & $5.60 \pm 0.20^{\mathrm{a}}$ & $7.21 \pm 0.52^{\mathrm{b}}$ \\
$\mathrm{Cd}$ & $17.52 \pm 0.44$ & $83.93 \pm 0.85^{\mathrm{a}}$ & $55.53 \pm 0.31^{\mathrm{b}}$ \\
$\mathrm{Hg}$ & $0.0142 \pm 0.0005$ & $0.0740 \pm 0.0002^{\mathrm{a}}$ & $0.0429 \pm 0.0006^{\mathrm{b}}$ \\
$\mathrm{Pb}$ & $\mathrm{ND}$ & $0.341 \pm 0.0055^{\mathrm{a}}$ & $0.293 \pm 0.0078^{\mathrm{b}}$ \\
$\mathrm{Se}$ & $10.81 \pm 0.10$ & $31.67 \pm 0.42^{\mathrm{a}}$ & $32.14 \pm 0.72^{\mathrm{a}}$ \\
$\mathrm{Ni}$ & $\mathrm{ND}$ & $\mathrm{ND}$ & $\mathrm{ND}$ \\
\hline $\mathrm{a}, \mathrm{b} \mathrm{F}$ Followed by different letters in the same line demonstrated significant difference \\
$(p<0.05) ; \mathrm{ND}-$ not detected.
\end{tabular}

\subsection{Heavy metal content}

Heavy metal have attracted increasing attention due to the potential harm to human health. Therefore, the heavy metal content, including $\mathrm{Cr}, \mathrm{Cu}, \mathrm{Zn}, \mathrm{As}, \mathrm{Cd}, \mathrm{Hg}, \mathrm{Pb}$, Se and $\mathrm{Ni}$, of different samples are determined and listed in Table 3.

The liver of yellowfin tuna was rich in $\mathrm{Zn}, \mathrm{Cu}, \mathrm{Cd}$ and Se. Besides, $\mathrm{Cr}, \mathrm{Pb}$ and $\mathrm{Ni}$ were found below detection limits in tuan liver, which had been validated as carcinogens (Sandikci et al., 2019). However, the contents of $\mathrm{Cr}, \mathrm{Cu}, \mathrm{Zn}, \mathrm{As}, \mathrm{Cd}, \mathrm{Hg}, \mathrm{Pb}$ and Se were increased in both the protein powder samples prepared by Acid-pH and Alkalin-pH. The concentration effect may be directly related to the increase of heavy metal content, which cames mainly from the removal of water and lipids.

The heavy metal content, except As and Ni, in Alkalin-PP were significant $(p<0.05)$ lower than the protein powder prepared by Acid-PP. The highest contents of $\mathrm{Zn}$ and $\mathrm{Cu}$ were observed in Acid-PP, which were about twice of those of Alkalin-PP. Besides, Ni was not detected in both Acid-PP and Alkalin-PP. That was due to the hydroxide precipitation of heavy metal would occur under strong alkaline conditions (Yatim et al., 2018), and further removed by centrifugation during Alkalin-pH. The results indicated that Alkalin-pH was more powerful in the remval of heavy metal, and obtained the safer protein powder as a consequence.

\subsection{Functional properties}

The functional properties, including emulsifying activity (EA), emulsifying stability (ES), foaming capacity (FC), foaming stability (FS), fat absorption capacity (FAC) and solubility, of obtained Acid-PP, Alkali-PP and SPP are shown in Table 4.

\section{$E A$ and $E S$}

In comparison, Acid-PP had a significantly $(p<0.05)$ lower EA than Alkali-PP, but was significantly higher $(p<0.05)$ in ES. The emulsification could be promoted by adding protein, due to the protein containing both hydrophilic and hydrophobic groups. Therefore, the lower lipid content of Alkali-PP led 
Table 4. Functional properties of soybean protein powder (SPP) and the protein powders prepared by acid- (Acid-PP) and alkali-aided (Alkali-PP) pH-shifting.

\begin{tabular}{lcccccc}
\hline \multicolumn{1}{c}{ Samples } & $\begin{array}{c}\text { Emulsion activity } \\
\left(\mathbf{m}^{2} / \mathbf{g}\right)\end{array}$ & $\begin{array}{c}\text { Emulsion stability } \\
(\%)\end{array}$ & $\begin{array}{c}\text { Foaming capacity } \\
(\mathbf{m L} / \mathbf{g} \text { protein) }\end{array}$ & Foam stability (\%) & $\begin{array}{c}\text { Fat absorption } \\
\text { capacity (g oil/g } \\
\text { protein) }\end{array}$ & $\begin{array}{c}\text { Solubility (\%) } \\
\text { Acid-PP }\end{array}$ \\
\hline Alkali-PP & $2.49 \pm 0.05^{\mathrm{a}}$ & $67.41 \pm 0.50^{\mathrm{a}}$ & $20.90 \pm 0.31^{\mathrm{a}}$ & $99.01 \pm 0.77^{\mathrm{ab}}$ & $3.64 \pm 0.22^{\mathrm{a}}$ & $3.27 \pm 0.04^{\mathrm{a}}$ \\
SPP & $3.14 \pm 0.06^{\mathrm{b}}$ & $64.78 \pm 1.18^{\mathrm{b}}$ & $30.79 \pm 0.99^{\mathrm{b}}$ & $99.94 \pm 0.06^{\mathrm{a}}$ & $4.58 \pm 0.10^{\mathrm{b}}$ & $3.29 \pm 0.10^{\mathrm{a}}$ \\
\hline
\end{tabular}

a,b,c Different letters within a column demonstrated significant difference $(p<0.05)$.

to the more hydrophobic groups exposed in Alkali-PP than Acid-PP, which further contributed to the better EA of the Alkali-PP. As a result, the degree of emulsification would decrease due to flocculation and coalescence, but the decline rate would become slower and slower (Zhang et al., 2019). So, the better ES of Acid-PP might be related to it having a worse EA than Alkali-PP.

Compared with SPP, the EA of Acid-PP was significantly worse $(p<0.05)$. However, no significant difference $(p>0.05)$ was observed between Alkali-PP and SPP in both EA and ES, which reflected the potential of Alkali-PP as an emulsifier in industry.

\section{FC and FS}

The FC of Alkali-PP was significantly better $(p<0.05)$ than Acid-PP. However, there was no significant difference $(p>0.05)$ between the FS of Alkali-PP and Acid-PP, which were both close to $100 \%$. According to the report by Singh \& Sogi (2018), the better hydrophobicity of protein would lead to a stronger FC of protein. As discussed in section 3.3, more lipids could be removed by Alkali-pH, which resulted in the more hydrophobic groups exposed in Alkali-pH and the stronger hydrophobic of Alkali-PP.

In addition, no significant difference $(p>0.05)$ was observed between Alkali-PP and SPP in both FC and FS. However, the FC and FS of Alkali-PP were both significantly better $(p<0.05)$ than SPP. Therefore, the Alkali-PP could be used as foaming agent.

\section{FAC and solubility}

Chalamaiah et al. (2017) found that the protein with lower lipid content often had the better FAC, and Alkali-PP showed the better FAC compared with Acid-PP, as expected. Moreover, no significant difference $(p>0.05)$ was found in the protein solubility of Acid-PP and Alkali-PP. Furthermore, SPP exhibited a better solubility and a worse FAC than the protein powder samples prepared from tuna liver.

In summary, the protein powder prepared by Alkali-pH was better than that prepared by Acid-pH, especially in EA, FC and FAC. Compared with SPP, the Alkali-PP was weaker in ES and solubility, but stronger in FC, FS and FAC, so, the protein powder prepared by Alkali-pH from tuna liver could be used as alternative emulsifiers and foaming agents in the food industry.

\section{Conclusions}

This study demonstrated that the high-purity protein powder could be obtained from the liver of yellowfin tuna through the steps of $\mathrm{pH}$-shifting (Acid-pH or Alkali-pH) and freeze-drying. In addition, more protein could be recovered and more lipids could be removed by Alkali-pH than Acid-pH. Moreover, Alkalin-pH was also more powerful in the remval of special heavy metal, including $\mathrm{Cr}, \mathrm{Cu}, \mathrm{Zn}, \mathrm{As}, \mathrm{Hg}, \mathrm{Pb}$ and $\mathrm{Se}$. Besides, except for Glu, Pro, Gly, Cys, Val and Leu, no significant difference $(p>0.05)$ was found in the amino acid profile between Acid-PP and Alkali-PP. However, the protein powder prepared by Alkali-pH had better functional properties, particularly in EA, FC and FAC, than that prepared by Acid-pH.

Compared with commercial SPP, the Alkali-PP was better at FC, FS and FAC, and was similar at EA and ES. Therefore, the Alkali-PP shows promising potential for application in the food industry, and could be used as certain processing agent, such as nutritional supplement, emulsifier and foaming agent.

\section{Acknowledgements}

This work was financially supported by the National Natural Science Foundation of China (No. 31901740) and the Science and Technology Project of Zhejiang Province (No. LGN19C200018).

\section{References}

American Oil Chemists' Society - AOCS. (2009). Official methods and recommended practices of the AOCS ( $7^{\text {th }} \mathrm{ed}$.). Champaign: AOCS Press.

Antigo, J. L. D., Bergamasco, R. D., \& Madrona, G. S. (2018). Effect of ph on the stability of red beet extract (Beta vulgaris l.) microcapsules produced by spray drying or freeze drying. Food Science and Technology (Campinas), 38(1), 72-77. http://dx.doi.org/10.1590/1678-457x.34316.

Chalamaiah, M., Esparza, Y., Temelli, F., \& Wu, J. (2017). Physicochemical and functional properties of livetins fraction from hen egg yolk. Food Bioscience, 18, 38-45. http://dx.doi.org/10.1016/j.fbio.2017.04.002.

Chen, D., Song, J., Yang, H., Xiong, S., Liu, Y., \& Liu, R. U. (2016). Effects of acid and alkali treatment on the properties of proteins recovered from whole gutted grass carp (ctenopharyngodon idellus) using isoelectric solubilization/precipitation. Journal of Food Quality, 39(6), 707-713. http://dx.doi.org/10.1111/jfq.12236.

Daniel, D., Benetti, G. J., \& Partridge, J. S. (2016). Overview on status and technological advances in tuna aquaculture around the world. Advances in Tuna Aquaculture, 1, 1-19. http://dx.doi.org/10.1016/ B978-0-12-411459-3.00001-1. 
Fang, Y. Z., Ji, J. J., Zhang, H. Y., Liu, S. L., Liu, J. H., \& Ding, Y. T. (2019). Effect of extrusion cooking on physicochemical properties of tuna meat-based extrudates. Food Science and Technology (Campinas), 39(3), 627-634. http://dx.doi.org/10.1590/fst.36617.

Fang, Y. Z., Liu, J. H., Li, J. H., Chen, W. W., Huang, G. R., \& Ding, Y. T. (2020). Rapid preparation of protein powder from high-moisture tuna liver: new insight into subcritical dimethyl ether. Lebensmittel-Wissenschaft + Technologie, 124, 109179. http://dx.doi.org/10.1016/j.lwt.2020.109179.

Joint WHO/FAO/UNU Expert Consultation. (2007). Protein and amino acid requirements in human nutrition. World Health Organization Technical Report Series, 935, 1-8. PMid:18330140.

Kristinsson, H. G., Theodore, A. E., Demir, N., \& Ingadottir, B. (2010). A comparative study between acid-and alkali-aided processing and surimi processing for the recovery of proteins from channel catfish muscle. Journal of Food Science, 70(4), 298-306. http://dx.doi.org/10.1111/j.1365-2621.2005.tb07177.x.

Navarro-Peraza, R. S., Osuna-Ruiz, I., Lugo-Sanchez, M. E., PachecoAguilar, R., Ramirez-Suarez, J. C., Burgos-Hernandez, A., MartinezMontano, E., \& Salazar-Leyva, J. A. (2020). Structural and biological properties of protein hydrolysates from seafood by-products: a review focused on fishery effluents. Food Science and Technology (Campinas), 40(1, Suppl 1), 1-5. http://dx.doi.org/10.1590/fst.24719.

Neves, A. C., Harnedy, P. A., O’Keeffe, M. B., \& FitzGerald, R. J. (2017). Bioactive peptides from Atlantic salmon (Salmo salar) with angiotensin converting enzyme and dipeptidyl peptidase IV inhibitory, and antioxidant activities. Food Chemistry, 218, 396-405. http://dx.doi.org/10.1016/j.foodchem.2016.09.053. PMid:27719926.

Piotrowicz, I. B. B., \& Salas-Mellado, M. M. (2017). Protein concentrates from defatted rice bran: preparation and characterization. Food Science and Technology (Campinas), 37(1, Suppl 1), 165-172. http://dx.doi.org/10.1590/1678-457x.34816.
Pires, C., Costa, S., Batista, A. P., Nunes, M. C., Raymundo, A., \& Batista, I. (2012). Properties of protein powder prepared from Cape hake by-products. Journal of Food Engineering, 108(2), 268-275. http://dx.doi.org/10.1016/j.jfoodeng.2011.08.020.

Sandikci, S., Tarhan, D., Aksu, F. Y., Özsobaci, N. P., Or, E., \& Bartcu, U. B. (2019). Levels of chromium, copper, iron, magnesium, manganese, selenium, zinc, cadmium, lead and aluminium of honey varieties produced in Turkey. Food Science and Technology (Campinas), 39(2), 392-397. http://dx.doi.org/10.1590/fst.19718.

Singh, T. P., \& Sogi, D. S. (2018). Comparative study of structural and functional characterization of bran protein concentrates from superfine, fine and coarse rice cultivars. International Journal of Biological Macromolecules, 111, 281-288. http://dx.doi.org/10.1016/j. ijbiomac.2017.12.161. PMid:29320723.

Taskaya, L., Chen, C., Beamer, S., \& Jaczynski, J. (2010). Texture and colour properties of proteins recovered from whole gutted silver carp (hypophthalmichthys molitrix) using isoelectric solubilisation/ precipitation. Journal of the Science of Food and Agriculture, 89(2), 349-358. http://dx.doi.org/10.1002/jsfa.3461.

Teh, S.-S., Bekhit, A. E.-D., Carne, A., \& Birch, J. (2014). Effect of the defatting process, acid and alkali extraction on the physicochemical and functional properties of hemp, flax and canola seed cake protein isolates. Journal of Food Measurement and Characterization, 8(2), 92-104. http://dx.doi.org/10.1007/s11694-013-9168-x.

Yatim, N. I., Ariffin, M. M., \& Hamzah, S. (2018). Removal of heavy metals using self-integrating bio-adsorbent from agricultural by-products and marine waste materials. Desalination and Water Treatment, 118(1), 216-229. http://dx.doi.org/10.5004/dwt.2018.22622.

Zhang, Y., Zhou, X., Zhong, J., Tan, L., \& Liu, C. (2019). Effect of ph on emulsification performance of a new functional protein from jackfruit seeds. Food Hydrocolloids, 93(9), 325-334. http://dx.doi.org/10.1016/j.foodhyd.2019.02.032. 